\title{
Morphological Characterization of Corynespora cassiicola Isolates in Culture Media
}

\author{
Jacqueline Dalbelo Puia ${ }^{1}$, Adriano Thibes Hoshino ${ }^{1}$, Estela Mariani Klein ${ }^{1}$, Emily Danila De Almeida ${ }^{2}$, \\ Sandra Cristina Vigo ${ }^{2} \&$ Marcelo Giovanetti Canteri ${ }^{1}$ \\ ${ }^{1}$ Agronomy Department, Universidade Estadual de Londrina, Rodovia Celso Garcia Cid, Londrina, Brazil \\ ${ }^{2}$ Department of Phytopathology, Instituto de Desenvolvimento Rural do Paraná, Londrina, PR, Brazil \\ Correspondence: Jacqueline Dalbelo Puia, Agronomy Department, Universidade Estadual de Londrina, Londrina, \\ PR, Brazil. Tel: 55-43-3376-2114. E-mail: puia.agro@gmail.com
}

Received: July 21, $2021 \quad$ Accepted: September 1, $2021 \quad$ Online Published: October 15, 2021

doi:10.5539/jas.v13n11p74 URL: https://doi.org/10.5539/jas.v13n11p74

The research is financed by "Coordenação de Aperfeiçoamento de Pessoal de Nivel Superior"-Brasil (CAPES).

\begin{abstract}
Corynespora cassiicola threatens soybean and cotton production in Brazil. The objective of this study was to evaluate cultural and morphological aspects of $C$. cassiicola isolated from soybean and cotton of different Brazilian regions, in culture media. The isolates were grown in PDA (Potato Dextrose Agar) and V8 juice agar media. The characteristics evaluated were: color, aspect, and growth rate of mycelia, as well as production and dimension of conidia, and number of septa per conidium. Culture media and isolates were compared using the Kruskal-Wallis or Tukey's test at 5\% significance level. The mycelia of the isolates were predominantly dark gray and light brown. C. cassiicola isolates grew better in V8 juice agar medium, presenting a higher mycelial growth rate. In PDA medium, the production of conidia was higher in isolates from cotton, compared with soybean isolates. There was great variation in the production of conidia in V8 juice agar medium, regardless of the host origin. Conidia length and width varied for isolate and culture medium. The isolates of $C$. cassiicola coming from cotton presented a higher number of septa per conidium when grown in PDA medium. The morphological aspects of C. cassiicola vary depending on the host of origin and the culture medium.
\end{abstract}

Keywords: conidia production, mycelial growth, target spot, V8 juice agar medium, PDA medium

\section{Introduction}

The fungus Corynespora cassiicola Berk. \& M. A. Curtis (Wei, 1950), present in countries with tropical and subtropical climates, causes diseases in more than 530 plant species belonging to 400 different genera (Farr et al., 2019). This fungus has a wide range of economically important hosts including soybean (Glycine max) (Seaman et al., 1965) cotton (Gossypium hirsutum) (Fulmer et al., 2012), common bean (Phaseolus vulgaris) (Mendes et al., 1998), papaya (Carica papaya) (Qi et al., 2011), cucumber (Cucumis sativum) (Cutrim \& Silva, 2003), pepper (Capsicum annuum) (Shimomoto, 2008) rubber tree (Hevea brasiliensis) (Qi et al., 2011), and tomato (Lycopersicon esculentum) (Lopes \& Ávila, 2005).

Severe epidemics of Corynespora cassiicola have been recorded in the USA, Brazil, and Argentina, where soybean and cotton are grown in crop rotation (Galbieri et al., 2014), leading to an increasing incidence of target spot in the last harvests of these crops (Sumabat et al., 2018; Godoy et al., 2020).

C. cassiicola causes a disease in soybean known as target spot, affecting leaves, stems, pods, and seeds (Almeida et al., 2005). In the leaves, the lesions appear as brown spots with yellow halos, evolving from light to dark brown necrotic patches of up to 2 centimeters in diameter surrounded by chlorotic halos (Snow \& Berggren, 1989). The severely affected leaves fall prematurely (Sinclair \& Backman, 1989).

The fungus survives in debris, soybean seeds, and fallow fields for up to two years. It forms survival structures called chlamydospores (Almeida et al., 2001; Godoy et al., 2014) that are specialized structures resistant to adverse environmental conditions, acting as resting spores (Gould, 2010; Kimati et al., 1995). 
In culture media, $C$. cassiicola initially presents white mycelium, later becoming light brown to dark gray (Snow \& Berggren, 1989). Conidiophores are formed isolated or in small groups, branched, erect or slightly curved, whose conidia occur without stroma formation (Ellis, 1971b). Formed isolated or in chains, conidia are cylindrical or oblavate, straight or slightly curved, from hyaline to brown or light olivaceous, and may have from zero to 28 septa, and a pronounced hilum at the base (Snow \& Berggren, 1989; Koenning \& Creswell, 2006).

Isolates of C. cassiicola from soybean have an optimum temperature for mycelial growth between 18 to $21^{\circ} \mathrm{C}$, with a minimum that allows in vitro growth from 5 to $7{ }^{\circ} \mathrm{C}$ and a maximum from 34 to $39{ }^{\circ} \mathrm{C}$ (Sinclair \& Backman, 1989).

Studies on morphology characteristics of C. cassiicola isolates and how they develop in different culture media are useful to define which culture medium favors the growth and sporulation of the isolates. In the literature, morphological variations among $C$. cassiicola isolates from different Brazilian regions are reported (Nghia et al., 2008; Qi et al., 2011; Kurre et al., 2019).

In addition, information about the pathogen's physiology and variations among isolates from different hosts and regions may guide which management strategies best control the disease (De Azevedo, 1997). These data allow choosing the more suitable technique to multiple the pathogen and to obtain inoculum for the selection of host plant lines that are less susceptible to the disease regarding different isolates.

In light of the above, this study aimed to determine the mycelial growth capacity and morphological characteristics of eight $C$. cassiicola isolates from soybean and cotton of different regions of Brazil, grown in PDA and V8 juice agar culture media.

\section{Method}

\subsection{Collection Soybean and Cotton Leaf Samples}

Samples of soybean and cotton leaves with typical target spot symptoms were collected in the 2018/19 harvest, in different areas of cultivation covering three Brazilian states (Figure 1). These samples were sent to the Seed Pathology laboratory at the Rural Development Institute IAPAR-EMATER, IDR-Paraná for analysis of symptoms in a microscope and subsequent pathogen isolation.

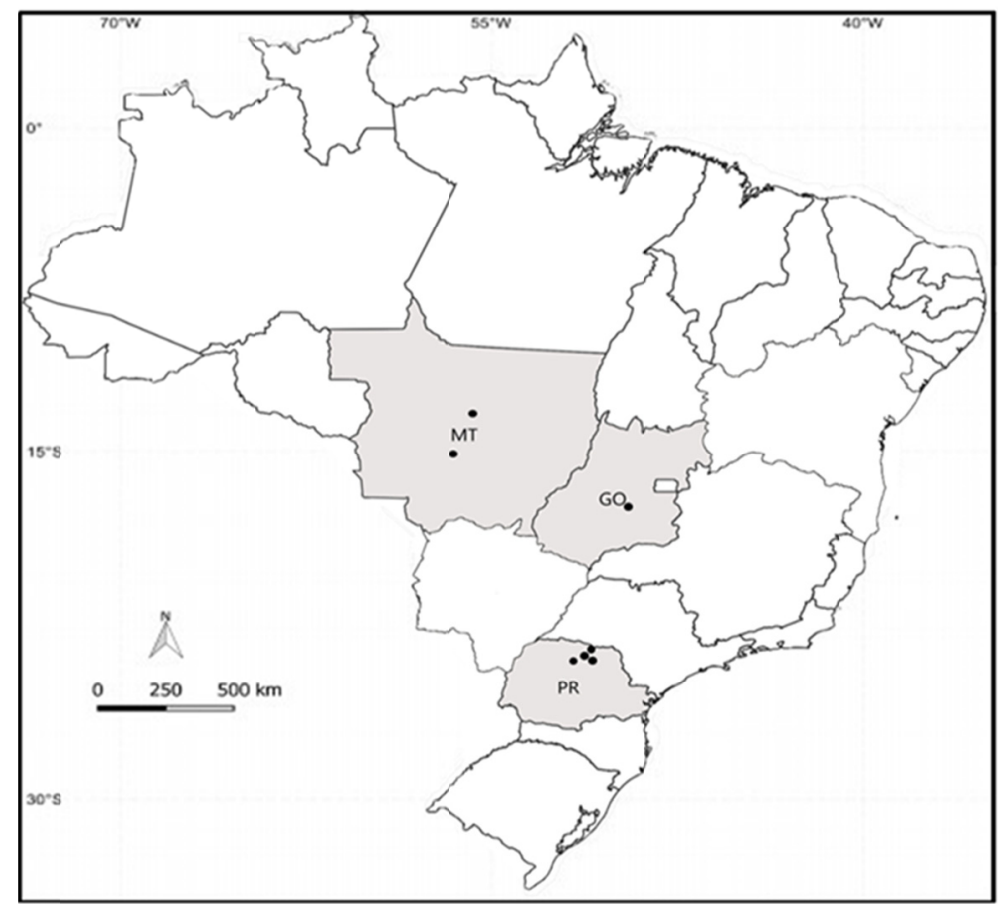

Figure 1. Map of Brazil showing the locations in three states where samples of soybean and cotton leaves with symptoms of target spot were collected to obtain isolates of Corynespora cassiicola 


\subsection{Pathogen Isolation, Purification, Identification, and Cultivation}

Soybean and cotton leaf segments ( $3 \mathrm{~mm}$ in diameter) containing lesions were subjected to superficial disinfestation in $70 \%$ alcohol for 30 seconds and $2 \%$ sodium hypochlorite for 1 minute, followed by washes in sterile distilled water. The tissues were distributed in V8 juice agar culture medium and maintained at $25 \pm 1{ }^{\circ} \mathrm{C}$ and $12 / 12 \mathrm{~h}$ light-dark photoperiod for pathogen isolation.

After four days, the mycelial growth of the fungus was observed and identified using the key of the genus $C$. cassiicola proposed by (Ellis, 1957). Then, the mycelium of each isolate was subcultured in V8 juice agar, and, subsequently, a monosporic culture was performed in agar-water medium (Fernandez, 1993). Each isolate was stored at $\pm 4^{\circ} \mathrm{C}$ using the method proposed by Castellani (Figueiredo, 1967).

Eight isolates of $C$. cassiicola species were obtained from soybean plants, named ISO S-soybean and cotton plants as ISO C-cotton, from the states of Paraná (PR), Mato Grosso (MT) and Goiás (GO) (Table 1). For a more detailed identification of the isolates, in addition to morphological characterization described here, a pathogenicity test was also performed. All isolates studied here underwent pathogenicity tests in different crops, and soybean and cotton (data not yet published) were pathogenic.

Table 1. Code, year, and location of collection and plant host species of Corynespora cassiicola isolates used in cultural and morphological analyses

\begin{tabular}{llll}
\hline Code & Year & Location & Host plant species \\
\hline ISO 1 S & 2018 & Goiânia-GO & \\
ISO 2 S & 2018 & Arapongas-PR & Glycine max L. \\
ISO 3 S & 2018 & Sorriso-MT & \\
ISO 4 S & 2019 & Londrina-PR & \\
ISO 11 S & 2018 & Diamantino-MT & \\
ISO 1 C & 2018 & Sertanópolis-PR & \\
ISO 2 C & 2019 & Jataizinho-PR & \\
ISO 3 C & 2019 & Porecatu-PR & \\
\hline
\end{tabular}

Mycelial discs of $5 \mathrm{~mm}$ in diameter were removed from the edges of the colonies after five days of growth and transferred to the center of Petri dishes $(\varnothing=9 \mathrm{~cm})$ containing Potato Dextrose Agar (PDA: $200 \mathrm{~g} \mathrm{~L}^{-1}$ potato extract, $20 \mathrm{~g} \mathrm{~L}^{-1}$ dextrose, $17 \mathrm{~g} \mathrm{~L}^{-1}$ agar) and V8 juice agar (V8: $5 \mathrm{~g} \mathrm{~L}^{-1}$ Calcium carbonate, $340 \mathrm{~mL}$ V8 juice, 34 $\mathrm{g} \mathrm{L}^{-1}$ agar). The dishes were sealed with Parafilm ${ }^{\circledR}$ and maintained at $25 \pm 1{ }^{\circ} \mathrm{C}$ and $12 / 12 \mathrm{~h}$ light-dark photoperiod for 72 hours. After this period, the evaluations were performed.

\subsection{Evaluations}

The variables evaluated were: color, aspect, and growth rate of mycelia, as well as production, length, width of conidia, and number of septa per conidium. The necessary evaluations to calculate the mycelial growth rate were performed from three to eleven days after incubation. The other evaluations were carried out 12 days after incubation.

Colony color was characterized following the color annotation system of Munsell Color Company (1975). The dishes containing PDA and V8 juice agar culture media were analyzed for colony pigmentation hue at both sides (front and back). The isolates were also evaluated for mycelium type: plane, aerial, or aerial cottony (Snow \& Berggren, 1989).

The daily rate of isolates mycelial growth was established by measuring the colony in two orthogonal directions, at 3, 5, 7, 9, and 11 days after incubation. The measurements were completed when the colony grew all over the Petri dish in one of the treatments (11 D.A.I.). However, the 9 D.A.I. evaluation was used to calculate the daily growth rate, since, at 11 D.A.I., mycelial growth may have been limited and could have interfered with the results. The daily rate $\left(\mathrm{mm} \mathrm{d}^{-1}\right)$ was calculated by the average diameter of the two diametrically opposed measurements subtracted from $\varnothing 0.5 \mathrm{~mm}$ (initial disc) and divided by 9 (evaluation days).

For conidia production, $10 \mathrm{~mL}$ of distilled water was added to each plate and the fungal colonies were scraped with a soft bristle brush. The concentration of the conidia suspension (conidia $\mathrm{mL}^{-1}$ ) was determined in a Neubauer chamber under a microscope at 100x magnification. The counting was performed five times for each repetition, and the average number was used to define the final amount of conidia. 
Conidia width and length $(\mu \mathrm{m})$ and number of septa were determined by evaluating 50 conidia of the fungal suspension described above. The structures were observed under optical microscopy $(100 \times)$, photographed, and subjected to the digital image processing and analysis software ImageJ version 1.32j (Wayne Rasband National Institute of Health, USA) (Rasband, 2012).

\subsection{Experimental Design and Statistical Analysis}

The experimente was conducted using a completely randomized design in a $2 \times 8$ factorial scheme (two culture media x eight $C$. cassiicola isolates) with five repetitions. The experimental unit consisted of a plate.

For the variables mycelial growth rate, conidia production, and average number of septa per conidium, the comparison between culture media within each isolate of $C$. cassiicola was performed by the non-parametric Mann-Whitney test. The comparison of isolates within each culture medium was performed using the Kruskal-Wallis test, at a significance level of 5\% using the BioEstat 5.0 software.

The variables conidia length and width were subjected to analysis of variance (ANOVA), followed by the mean comparison Tukey's test at 5\% significance level, comparing culture media and C. cassiicola isolates in a factorial scheme. The software used was SISVAR.

\section{Results}

\subsection{Colony Pigmentation and Appearance}

Great variation was observed in the pigmentation of the eight $C$. cassiicola isolates grown in PDA and V8 juice agar culture media (Table 2 and Figure 2).

At the superior part (front) of the dishes containing V8 juice agar medium, the mycelial pigmentation of the isolates varied from gray to olivaceous, while at the inferior part (back) of the dishes, light brown was the predominant color for all isolates (Figure 2). In PDA medium, mycelial pigmentation varied from gray to white at the front of the dishes and from brown to black at the back of the dishes (Figure 2).

In general, the mycelial color of $C$. cassiicola isolates was predominantly dark gray and light brown, at the front and back of the plates, respectively.

Regardless of the culture medium, the mycelial aspect of the isolates from cotton was plane, while, for soybean isolates, the mycelial aspect was aerial cottony. The only exception was the ISO 1S isolate, which proved to be plane when grown in both culture media (Table 2). 


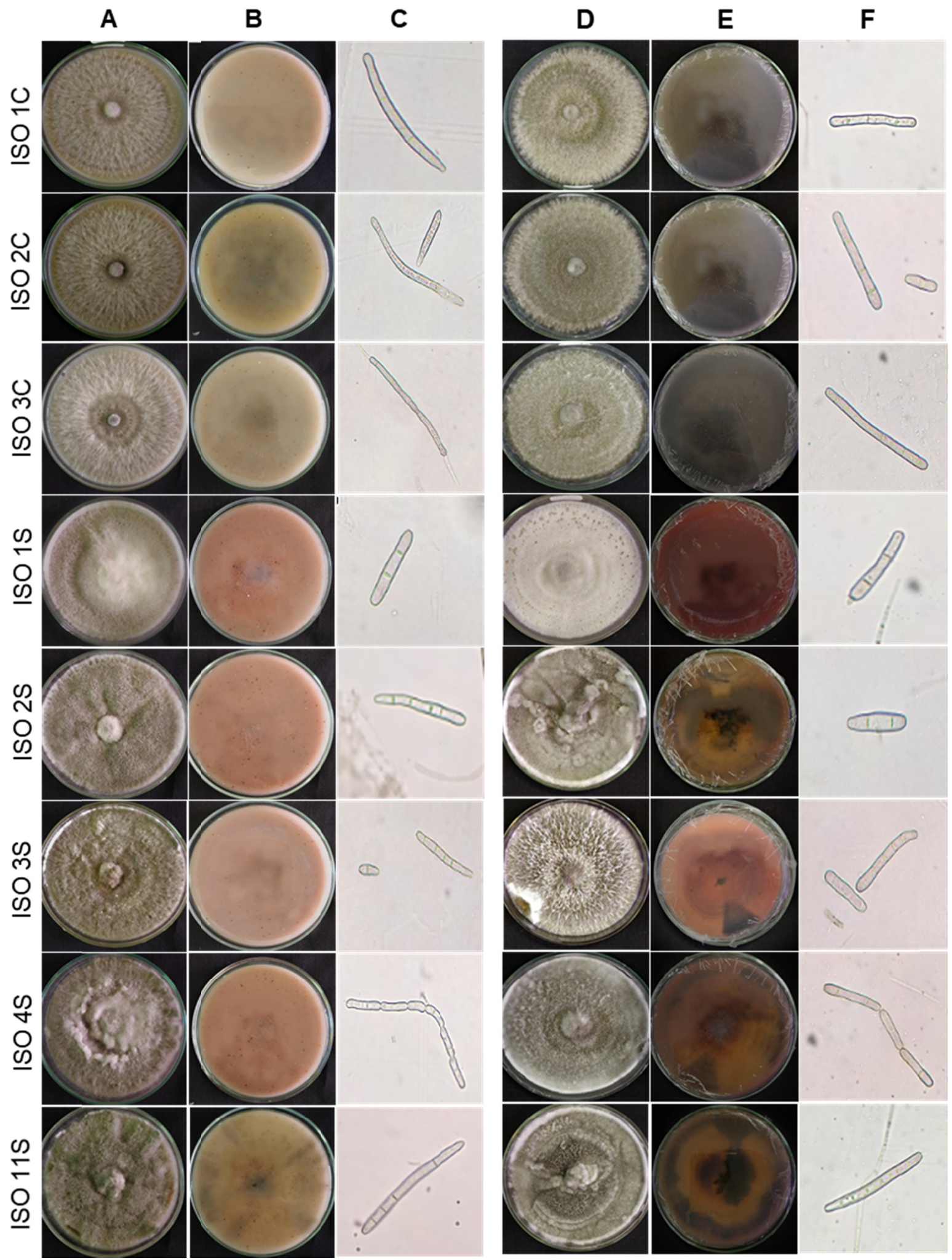

Figure 2. Morphological characteristics of Corynespora cassiicola isolates at 12 days of incubation in V8 juice agar and PDA culture media, $\mathrm{T}^{\circ}=25 \pm 1{ }^{\circ} \mathrm{C}$ and 12 -hour photoperiod. (A) Front view of the dishes in Juice V8 agar medium; (B) Back view of the dishes with V8 juice agar medium; (C and F) Microscopic images of different shapes, septa and conidia sizes of $C$. cassiicola visualized in juice V8 agar and PDA; (D) Front view of the dishes with PDA medium; (E) Back view of the dishes with PDA medium 


\subsection{Mycelial Growth Rate}

The mycelial growth rate $\left(\mathrm{mm} \mathrm{d}^{-1}\right)$ varied from 5.40 to $8.82 \mathrm{~mm} \mathrm{~d}^{-1}$ among the eight isolates of C. cassiicola (Table 2). The highest mycelial growth rate occurred for isolates grown in V8 juice agar produc, with 8.40 to $8.82 \mathrm{~mm} \mathrm{~d}^{-1}$, while the values ranged from 5.40 to $7.30 \mathrm{~mm} \mathrm{~d}^{-1}$ in PDA produc.

Mycelium of $C$. cassiicola isolates grew at production rates in PDA, with the highest growth rates observed for ISO $3 \mathrm{C}$ and ISO $1 \mathrm{C}$, presenting 7.30 and $7.14 \mathrm{~mm} \mathrm{~d}^{-1}$, respectively. The lowest growth rates occurred for the isolates ISO 4S, ISO $11 \mathrm{~S}$, and ISO $3 \mathrm{~S}$, with $6.35,6.00$, and $5.40 \mathrm{~mm} \mathrm{~d}^{-1}$, respectively. Whereas for the V8 juice agar culture produc, no significant differences were detected regarding the mycelial growth rate of $C$. cassiicola isolates (Table 2).

\subsection{Conidia Production}

The performance of conidia production in the different culture media varied according to the plant host origin of the isolates (Table 2). No difference was observed in the production of conidia between the culture media when the isolates came from cotton plants (ISO 1C, ISO 2C, and ISO 3C). Whereas regarding C. cassiicola isolates from soybean plants, conidia production was higher for the ISO 2S, ISO 4S, and ISO 11S isolates in V8 juice agar medium $(64.00,99.13$, and 107.38, respectively), compared with the PDA medium $(23.88,36.00$, and 38.00 , respectively) (Table 2).

In general, the production of conidia in PDA medium was higher in isolates from cotton, with 88.50 to 90.63 conidia $\mathrm{mL}^{-1}$, compared to soybean isolates, ranging from 19.13 to 43.13 conidia $\mathrm{mL}^{-1}$.

When the isolates were cultivated in V8 juice agar medium, the highest number of conidia was produced by the isolates ISO $11 \mathrm{~S}$, ISO $4 \mathrm{~S}$, ISO $2 \mathrm{C}$, and ISO $1 \mathrm{C}$, producing from 107.38 to 85.00 conidia $\mathrm{mL}^{-1}$, in relation to ISO $3 \mathrm{~S}$ and ISO $1 \mathrm{~S}$, with 49.38 and 22.88 conidia $\mathrm{mL}^{-1}$, respectively (Table 2 ).

Table 2. Colony cultural and morphological aspects, growth rate, conidia production, conidia length and width, and number of septa in eight isolates of Corynespora cassiicola (C. c.) obtained from cotton and soybean and grown in PDA and V8 juice agar (V8) culture media after 12 days of incubation at $25 \pm 1{ }^{\circ} \mathrm{C}$ and $12 / 12 \mathrm{~h}$ photoperiod.

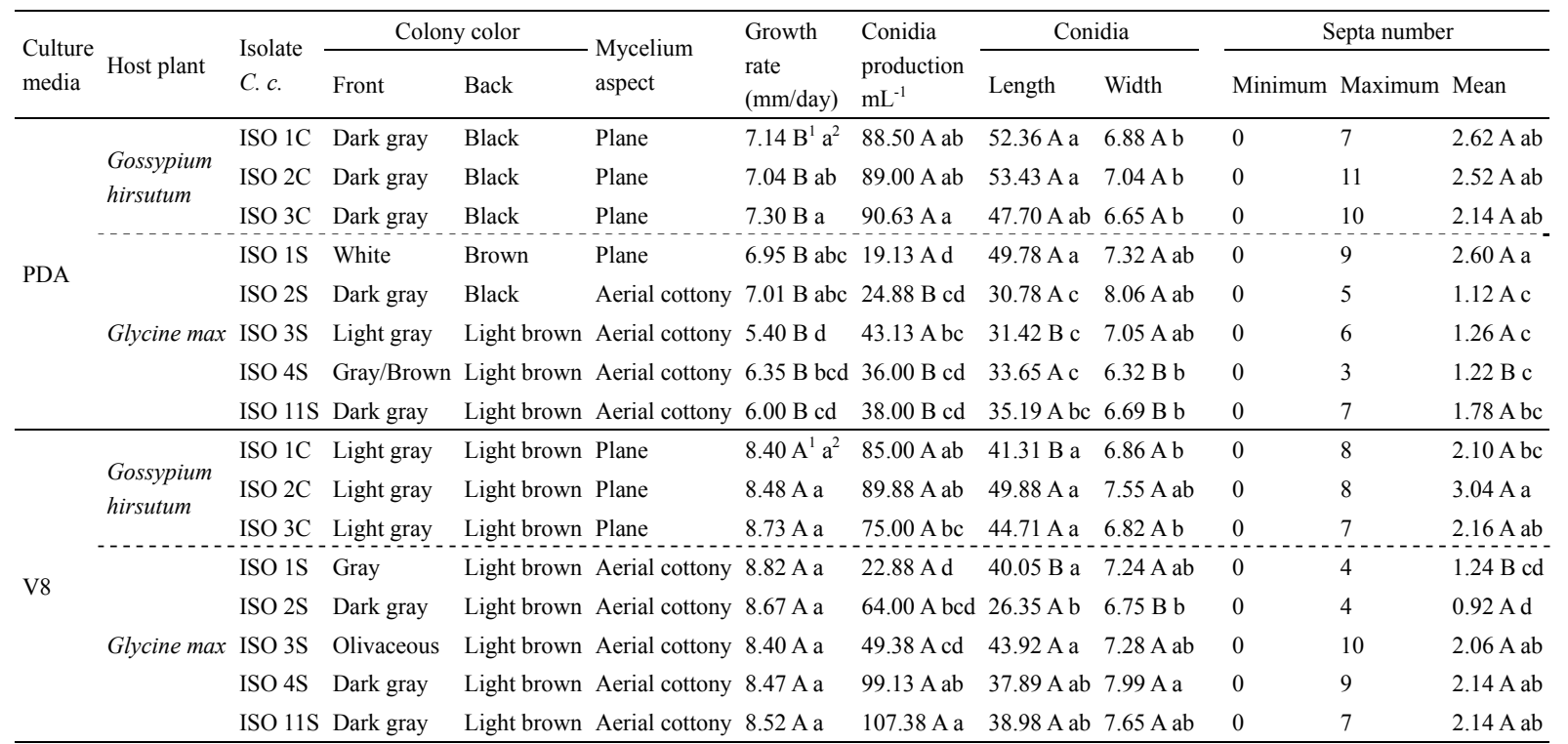

Note. ${ }^{1}$ Means followed by capital letters in the column compare culture media within each isolate of C. cassiicola, different letters indicate significant difference $(\alpha=5 \%)$ by the Mann-Whitney test.

${ }^{2}$ Means followed by lowercase letters in the column compare isolates of $C$. cassiicola within each culture medium, indicating significant difference $(\alpha=5 \%)$ by the Kruskal-Wallis test.

\subsection{Conidia Dimensions}

In the two culture media tested, all isolates produced conidia and their length and width were determined. However, there was an interaction between culture medium and isolates of $C$. cassiicola (Table 2). The isolates ISO 1C $(52.36 \mu \mathrm{m})$ and ISO 1S $(49.78 \mu \mathrm{m})$ showed greater lengths of conidia produced in the PDA medium, 
while the ISO 3S isolate had greater conidium length $(43.92 \mu \mathrm{m})$ in V8 juice agar. The other isolates did not differ from each other (Table 2).

The highest length of conidia produced in PDA medium was observed for the isolates ISO 3C, ISO 1S, ISO 1C, and ISO $2 \mathrm{C}$, ranging from 47.70 to $53.43 \mu \mathrm{m}$. The shortest length was observed for ISO 2S, ISO 3S, and ISO 4S, presenting 30.78 to $33.65 \mu \mathrm{m}$. The longest conidia length obtained in V8 juice agar medium was found for ISO $1 \mathrm{~S}$, ISO $1 \mathrm{C}$, ISO 3S, ISO 3C, and ISO $2 \mathrm{C}$, showing from 40.05 to $49.88 \mu \mathrm{m}$ and differing from the ISO $2 \mathrm{~S}$ isolate $(26.35 \mu \mathrm{m})$.

No difference was observed in the width of conidia grown in PDA or V8 juice agar when the isolates came from cotton (Table 2). However, for isolates from soybean plants, the ISO $2 \mathrm{~S}$ isolate had a greater conidial width in the PDA medium $(8.06 \mu \mathrm{m})$ compared with those produced in V8 juice agar $(6.75 \mu \mathrm{m})$. The opposite occurred when the ISO 4S and ISO 11S isolates were grown in V8 juice agar medium, with 7.99 and $7.65 \mu \mathrm{m}$, compared with the values of 6.32 and $6.69 \mu \mathrm{m}$ obtained in the PDA medium. The other isolates did not differ from each other (Table 2).

When grown in PDA medium, the largest conidia width was observed for ISO 2S, with $8.06 \mu \mathrm{m}$, differing from ISO 4S, ISO 11S, ISO 3C, ISO 1C, and ISO 2C, whose dimensions varied from 6.32 to $7.04 \mu \mathrm{m}$. Regarding the V8 juice agar culture medium, the largest conidium width was observed for the ISO $4 \mathrm{~S}$ isolate, with $7.99 \mu \mathrm{m}$, while the ISO 2S, ISO 3C, and ISO 1C isolates had the smallest widths ranging from 6.75 to $6.86 \mu \mathrm{m}$ (Table 2).

\subsection{Number of Septa}

For most isolates of $C$. cassiicola, the number of septa per conidium varied greatly, regardless of the culture medium (Table 2 and Figure 3). In all isolates, the presence of conidia without septa was observed. The maximum number of septa varied from 3 for the ISO $4 \mathrm{~S}$ isolate to 11 in ISO $2 \mathrm{C}$.

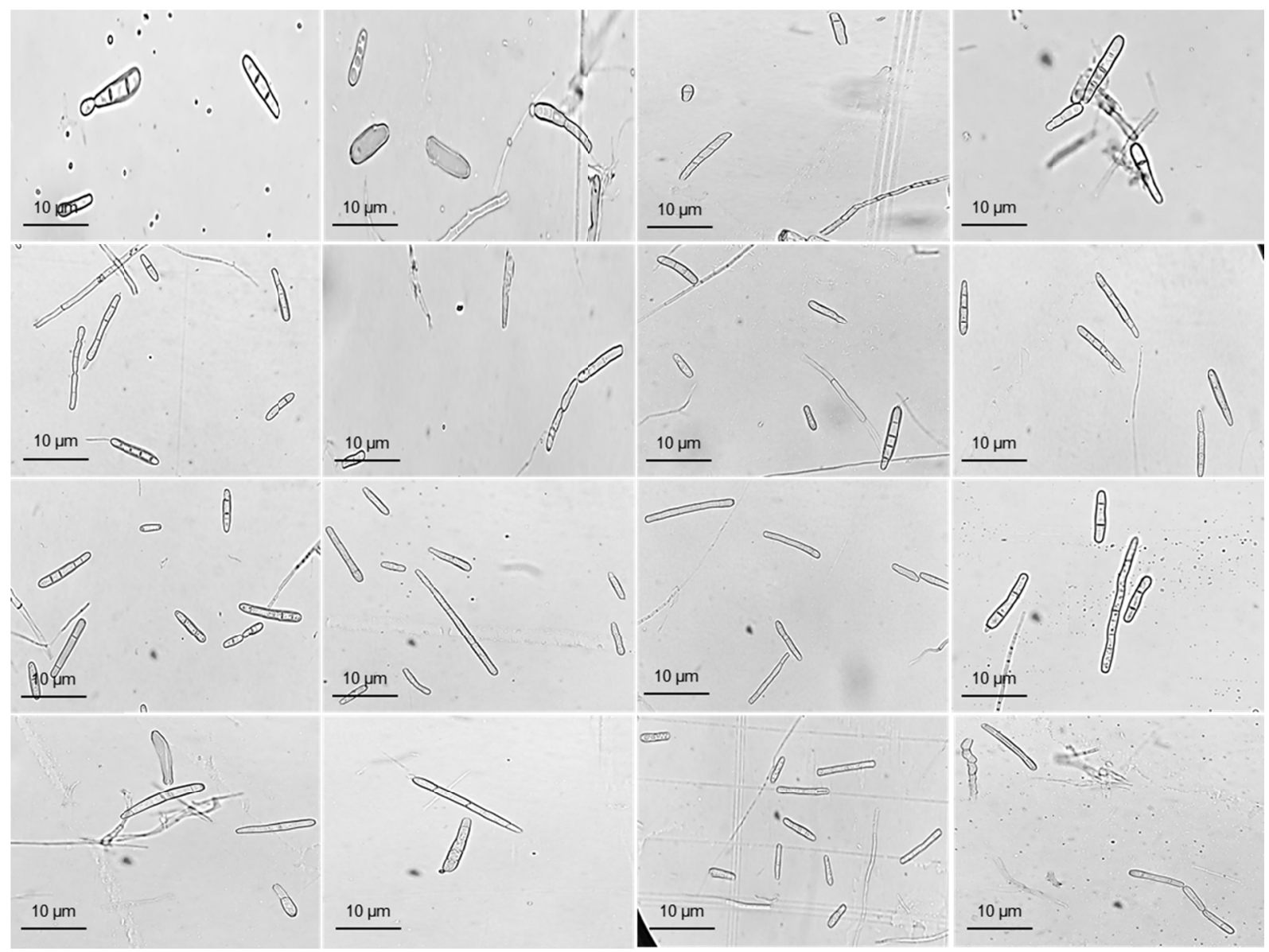

Figure 3. Morphocultural variability observed under a microscope produced by eight isolates of Corynespora cassiicola from different regions 
No difference was found between the culture media tested regarding the average number of septa per conidium of $C$. cassiicola isolates from cotton plants (Table 2). However, differences were observed for isolates from soybean. ISO 1S had the highest average number of septa per conidium when grown in PDA medium, with 2.60 septa per conidium, compared with 1.24 septa per conidium in the V8 juice agar medium.

The opposite occurred for ISO 4S, with the highest average number of 2.14 septa per conidium in V8 juice agar medium, compared with PDA medium, where it produced 1.22 septa per conidium. The other isolates did not differ in terms of culture medium and average number of septa per conidium.

When grown in PDA medium, the average number of septa per conidium was higher for the ISO 3C, ISO 2C, ISO $1 \mathrm{~S}$, and ISO $1 \mathrm{C}$ isolates, ranging from 2.14 to 2.62 . Whereas ISO $2 \mathrm{~S}$, ISO $4 \mathrm{~S}$, and ISO $3 \mathrm{~S}$ presented 1.12 to 1.26 septa per conidium.

When isolates were cultivated in V8 juice agar medium, the highest average number of septa per conidium was observed for the isolates ISO 4S, ISO 11S, ISO 3C, and ISO 2C, with 2.14 to 3.04 septa per conidium, while the lowest average values were found for ISO $1 \mathrm{~S}$ and ISO 2S, which presented 1.24 and 0.92 septa per conidium, respectively (Table 2).

\section{Discussion}

Similarities were observed in the characteristics of the eight isolates by the description of (Ellis \& Holliday, 1971a), indicating that they belong to the species C. cassiicola. The study of fungi characteristics and morphological variations plays an important role in taxonomy and can assist in the identification of many pathogenic species (Mushrif, 2006).

In the present study, no variation was observed for characteristics related to the development of isolates from cotton; however, a great variation occurred for isolates from soybean. These results indicate that the host plant of the pathogen influences its developmental characteristics. These data corroborate previous studies, which described variations in color, texture, and dimensions of conidia between isolates of C. cassiicola from the same or different hosts and regions (Darmono et al., 1996; Spencer \& Walters, 1969).

Qi et al. (2011) and Sousa et al. (2014) studied C. cassiicola isolates from soybean grown in PDA medium and also found variations in texture, ranging from fine to thick, and colony color, being white to light brown, red-brown, dark brown, dark gray, or black.

Probably, the variability among isolates from soybean can be attributed to the older interaction between $C$. cassiicola and soybean plants compared with cotton plants (Almeida et al., 1976; Fulmer et al., 2012). This longer time of interaction, together with the presence of diverse soybean cultivars in different regions of Brazil, may have resulted in greater selection pressure for $C$. cassiicola pathotypes. However, further studies should be carried out to elucidate this hypothesis, using a greater number of isolates from soybean and cotton plants. It is worth mentioning that the variability of phytopathogens is related to the occurrence of some mechanisms of genetic recombination (Kaufmann, Weidemann, \& Peres, 2003).

The mycelial growth rate of $C$. cassiicola in other culture media was recorded from 5.7 to $10.0 \mathrm{~mm} \mathrm{~d}^{-1}$ for different isolates (Oliveira et al., 2007; Nghia et al., 2008). In this study, a lower mycelial growth rate was found for all isolates grown in PDA medium, ranging from 5.40 to $7.30 \mathrm{~mm} \mathrm{~d}^{-1}$, when compared with the values of 8.40 to $8.82 \mathrm{~mm} \mathrm{~d}^{-1}$ in V8 juice agar medium.

Almeida et al. (1994) and Muliterno de Melo (2009) also found that different isolates of C. cassiicola develop slowly in PDA culture medium, forming dark shaded mycelium with color from gray to olive black. The authors relate the slower mycelial growth with the source of nutrients to which the isolate has access and the use of nutrients in each culture medium.

Although the PDA medium is frequently used for studies with different fungi (Diener, 1952) warns that the development of some fungi may be impaired by it, proposing the use of a culture medium with industrialized juice (Juice V8) composed of eight vegetables, rich in vitamins A, C, and E, fiber, and minerals. This culture medium provided higher rates of mycelial growth in the present study.

For fungi cultivation in vitro, the choice of the medium must be based on nutrients and physico-chemical conditions that are indispensable for the development of the pathogen. In addition to temperature and brightness, the composition of the culture medium determines the quality and quantity of mycelial growth (Carnaúba et al., 2007).

Griffin (1993) reported that each isolate has a metabolizes nutrients at different speeds depending on the culture medium, leading to the synthesis of other molecules or products that influence the fungus growth in the medium. 
There is no ideal culture medium that is suitable for all pathogens, and it is necessary to compare media for growth and spore formation for each pathogen studied (Gava, 2002).

No differences were found in the production of conidia between the culture media when the isolates came from cotton plants. However, soybean-derived isolates reached the highest conidia production in the V8 juice agar medium, corroborating the results of (Almeida et al., 1976).

The higher production of spores in phytopathogens may be related to the medium in which it was grown (Carnaúba et al., 2007). For some phytopathogenic fungi, (Diener, 1952) recommends the use of a medium containing V8 juice in order to increase the production of conidia. As previously mentioned, this medium is rich in vitamins and minerals, which may partially justify the results found in this study since the PDA medium contains less concentration of vitamins and minerals.

Conidia length and width of the different isolates obtained in this study ranged from 26.35 to $53.36 \mu \mathrm{m}$ and from 6.65 to $8.06 \mu \mathrm{m}$, respectively. The number of septa varied from 0 to 11 septa per conidium. These dimensions and number of septa are in accordance with the lower and upper limits proposed by Ellis (1971a) for the species description.

Qi et al. (2011) also observed a difference in the conidia dimensions of C. cassiicola, with length from 10 to 277 $\mu \mathrm{m}$, width from 1.3 to $17.1 \mu \mathrm{m}$, and number of septa from 0 to 18 per conidium. For the same pathogen, (Teramoto, 2008) obtained dimensions from 46.1 to $110.9 \mu \mathrm{m}$ for length, from 5.3 to $8.2 \mu \mathrm{m}$ for width, and 1 to 15 for septa number. In studies with soybean isolates, (Ferreira, 2012) observed lengths of 20 to $300 \mu \mathrm{m}$, width of 7 to $15 \mu \mathrm{m}$, and number of septa varying from 1 to 22. Muliterno de Melo (2009) found conidia sizes from 8 at $280 \mu \mathrm{m}$, with an average of 10 to $150 \mu \mathrm{m}$.

The dimensions of conidia length and width as well as the number of septa obtained in this study showed less variation compared with the results brought in the literature. It can be seen that the values described by each author vary; these differences may be related to the origin of the isolates, such as host plant and geographical location, handling techniques, humidity of the environment in which they are grown, and the culture medium (Gasparotto \& Pereira, 2012; Sousa \& Bentes, 2014; Darmono et al., 1996; Spencer \& Walters, 1969). Sousa and Bentes (2014) also reported that in natural conditions with high humidity, conidiophores and conidia are generally long and sharp.

The knowledge of how the chemical composition of the culture media physiologically influence the pathogen $C$. cassiicola, affecting the morphological, growth, and production characteristics of conidia is essential to determine which culture medium allows the multiplication of the pathogen more efficiently under in vitro conditions (Bogo et al., 2008).

\section{References}

Almeida, A. M. R., Ferreira, L., \& Yorinori, J. (2005). Doenças da soja. In H. Kimati, L. Amorim, J. A. M. Rezende, A. Bergamin Filho, \& L. E. A. Camargo (Eds.), Manual de Fitopatologia (Vol II, pp. 569-88). Piracicaba: Editora Ceres.

Almeida, A. M. R., Machado, C. C., Ferreira, L. P., \& Lehman, O. S. (1976). Ocorrência de Corynespora cassiicola (Berk. \& Curt.) Wei no Estado de São Paulo. Fitopatologia Brasileira, 1(1), 111-112. Retrieved from http://www.sidalc.net/cgi-bin/wxis.exe/?IsisScript=AGRINTER.xis\&method=post\&formato=2\&canti $\mathrm{dad}=1 \&$ expresion $=\mathrm{mfn}=010368$

Almeida, Á. M. R., Saraiva, O. F., Farias, J. R. B., Gaudêncio, C. A., \& Torres, E. (2001). Survival of pathogens on soybean debris under no-tillage and conventional tillage systems. Pesquisa Agropecuária Brasileira, 36(10), 1231-1238. https://doi.org/10.1590/S0100-204X2001001000003

Almeida, A. M. R., Vasconcelos, M. J. V., Abdelnoor, R. V., Yorinori, J. T., Barros, E. G., \& Moreira, M. A. (1994). Diferenciação de isolados de Corynespora cassiicola. Fitopatologia Brasileira, 29, 316.

Bogo, A., Maffioletti, M. A., Sanhueza, R. M. V., \& Casa, R. T. (2008). Caracterização morfológica de isolados de Cryptosporiopsis perennans em diferentes meios de cultura. Brasília: Tropical Plant Pathology, 33(3), 248-251. https://doi.org/10.1590/S1982-56762008000300013

Carnaúba, J. P., Sobral, M. F., Amorim, E. D. R., Silva, J. C. D., Santos, V. B. D., \& Félix, K. D. S. (2007). Avaliação de diferentes meios de cultura na esporulação de Scytalidium lignicola. Summa Phytopathol, 33, 199-200. https://doi.org/10.1590/S0100-54052007000200018

Cutrim, F. A., \& Silva, G. S. (2003). Patogenicidade de Corynespora cassiicola para diferentes espécies de plantas. Fitopatologia Brasileira, 28, 193-194. https://doi.org/10.1590/S0100-41582003000200014 
Darmono, T. W., Darussamin, A., \& Pawirosoemardjo, S. (1996). Variation among isolates of Corynespora cassiicola associated with Hevea brasiliensis in Indonesia. Proceeding Workshop on Corynespora Leaf Fall Disease of Hevea Rubber, 16(17), 79-91.

De Azevedo, L. A. S. (1997). Manual de quantificação de doenças de plantas. Retrieved from https:/www.estantevirtual.com.br/livros/luis-antonio-siqueira-de-azevedo/manual-de-quantificacao-de-doen cas-de-plantas/1780509979

Diener, U. L. (1952). A method for inducing abundant sporulation of Stemphylium solani in purê culture. Phytopathology, 42(7).

Ellis, M. B. (1957). Some species of Corynespora. Mycological Papers, 65. CABI International. Retrieved from https://www.cabdirect.org/cabdirect/abstract/19571102326

Ellis, M. B. (1971b). Dematiaceous Hyphomycetes (p. 608). Surrey, Commonwealth Mycological Institute.

Ellis, M. B., \& Holliday, P. (1971a). Corynespora cassiicola [Target Spot]. CMI descriptions of pathogenic fungi and bacteria. CABI International. https://doi.org/10.1079/DFB/20056400303

Farr, D. F., Rossman, A. Y., Palm, M. E., \& Maccray, E. B. (2019). Fungal databases. Systematic Botany \& Mycology Laboratory, USDAARS.

Fernandez, M. R. (1993). Manual para laboratório de fitopatologia. Embrapa Trigo-Documentos (INFOTECA-E). Retrieved from https://www.infoteca.cnptia.embrapa.br/infoteca/handle/doc/815639

Ferreira, F. A. S. (2012). Caracterização morfológica e enzimática de isolados de Corynespora cassiicola e reação de cultivares de soja à mancha-alvo (p. 84, Tese de Doutorado, Tese (Doutorado em Agronomia), Universidade de Passo Fundo, Passo Fundo). Retrieved from http://tede.upf.br/jspui/handle/tede/521

Figueiredo, M. B. (1967). Estudos sobre a aplicação do método de Castellani para conservação de fungos patógenos em plantas. O Biológico, 33(1).

Fulmer, A. M., Walls, J. T., Dutta, B., Parkunan, V., Brock, J., \& Kemerait, J. R. C. (2012). First report of target spot caused by Corynespora cassiicola on cotton in Georgia. Plant Disease, 96(7) 1066-1066. https://doi.org/10.1094/PDIS-01-12-0035-PDN

Galbieri, R., Araújo, D. C., Kobayasti, L., Girotto, L., Matos, J. N., Marangoni, M. S., \& Mehta, Y. R. (2014). Corynespora leaf blight of cotton in Brazil and its management. American Journal of Plant Sciences, 5(26), 3805. https://doi.org/10.4236/ajps.2014.526398

Gasparotto, L., \& Pereira, J. C. R. (2012). Doenças da seringueira no Brasil (Vol. 2). Brasília: EMBRAPA.

Gava, M. A. (2002). Desempenho de diferentes meios de cultura utilizados na avaliação de fungos presentes em ambientes de produção de alimentos (Dissertação de Mestrado, Universidade de São Paulo, Brazil). Retrieved from https://teses.usp.br/teses/disponiveis/11/11138/tde-12082002-144728/publico/marcio.pdf

Godoy, C. V., Utiamada, C. M., Meyer, M. C., Campos, H. D., Lopes, I. de O. N., Dias, A. R., ... Carlin, V. J. (2020). Eficiência de fungicidas para o controle da mancha-alvo, Corynespora cassiicola, na safra 2019/20: Resultados sumarizados dos ensaios cooperativos. Embrapa Soja-Circular Técnica (INFOTECA-E). Portal Embrapa, Brazil. Retrieved from https:/www.embrapa.br/en/busca-de-publicacoes/-/publicacao/1123555/ eficiencia-de-fungicidas-para-o-controle-da-mancha-alvo-corynespora-cassiicola-na-cultura-da-soja-na-safr a-20192020-resultados-sumarizados-dos-ensaios-cooperativos

Godoy, C. V., Utiamada, C. M., Meyer, M. C., Campos, H. D., Pimenta, C. B., Jaccoud, F. D. B., ... Venancio, W. S. (2014). Eficiência de fungicidas para o controle da mancha-alvo, Corynespora cassiicola, na safra 2013/14: Resultados sumarizados dos ensaios cooperativos. Embrapa Soja-Circular Técnica (INFOTECA-E). Portal Embrapa, Brazil. Retrieved from https:/www.embrapa.br/en/busca-de-publicacoes/ -/publicacao/994254/eficiencia-de-fungicidas-para-o-controle-da-mancha-alvo-corynespora-cassiicola-na-sa fra-201314-resultados-sumarizados-dos-ensaios-cooperativos

Gould, A. B. (2010). Fungos fitopatogênicos e oomicetos. In R. N. Trigiano, M. T. Windham, \& A. S. Windham (Eds.), Fitopatologia: Conceitos e exercícios de laboratório (Vol. 2, pp. 102-120). Porto Alegre: Artmed.

Griffin, D. H. (1993). Fungal physiology (p. 458). New York: John Wiley. Retreved from https://onlinelibrary.wiley.com/doi/abs/10.1002/jctb.280640118

Kimati, H., Amorim, L., Bergamin Filho A., Camargo, L. E. A., \& Rezende, J. A. M. (1995). Manual de Fitopatologia: Princípios e conceitos (Vol. 2, pp. 645-671). São Paulo, Editora Agronômica Ceres Ltda. 
Retrieved from https://ppgfito.ufersa.edu.br/wp-content/uploads/sites/45/2015/02/Livro-Manual-de-Fitopa tologia-vol.2.pdf

Koenning, S. R., \& Creswell, T. C. (2006). Increased occurrence of target spot of soybean caused by Corynespora cassiicola in the Southeastern United States. Plant Disease, 90(7), 974-974. https://doi.org/10.1094/PD-90-0974C

Kurre, A. K., Dewangan, M., \& Nishad, D. (2019). Variability among Corynespora cassiicola isolates causing target leaf spot disease collected from soybean growing area of Chhattisgarh. Journal of Pharmacognosy and Phytochemistry, 8(6), 603-606. Retreved from https://www.phytojournal.com/archives/2019/vol8issue 6/PartJ/8-5-482-134.pdf

Lopes, C. A., \& Ávila, A. C. (2005). Doenças do Tomateiro (p. 151). Brasília: CNP Hortaliças.

Mendes, M. A. S., Silva, V. L., Dianese, J. C., Ferreira, M. A. S. V., Santos, C. E. N., Gomes, N. E., ... Castro, C. (1998). Fungos em plantas no Brasil (p. 569). Brasília: EMBRAPA/CENARGEN. Retreved from https://www.worldcat.org/title/fungos-em-plantas-no brasil/oclc/710883452?referer=di\&ht=edition

Muliterno, de M. M. (2009). Produção de esporos e inoculação de Corynespora cassiicola em soja (p. 76, Dissertação (Mestrado em Agronomia Fitopatologia Passo Fundo), Universidade de Passo Fundo). Retreved from http://tede.upf.br/jspui/bitstream/tede/483/1/2009MarciaMuliternodeMelo.pdf

Munsell Soil Color Company. (1975). Munsell soil color charts. Baltimore, USA.

Mushrif, S. K. (2006). Morphology, physiology and survival of Corynespora cassiicola (Bert. \& Curt.) Wei. In K. Jacob (Ed.), Corynespora leaf disease of Hevea brasiliensis. Strategy for management (pp. 26-32). Rubber Research Institute of India. https://doi.org/10.1007/s11046-008-9138-8

Nghia, N. A., Kadir, J., Sunderasan, E., Abdullah, M. P., Malik, A., \& Napis, S. (2008). Morphological and Inter Simple Sequence Repeat (ISSR) Markers Analyses of Corynespora Cassiicola Isolates from Rubber Plantations in Malaysia. Mycopathologia, 166, 189-201. https://doi.org/10.1007/s11046-008-9138-8

Oliveira, R. R., Vida, J. B., Tessmann, D. J., Aguiar, B. de M. A., Caixeta, M. P., \& Barboza, A. L. (2007). Patogenicidade de isolados de Corynespora cassiicola a diferentes espécies de plantas. Summa Phytopathologica, 33(3), 297-299. https://doi.org/10.1590/S0100-54052007000300016

Peres, A. P., Silva-Mann, R., Vieira, M. G. G. C., \& Machado, J. C. (2003). Variabilidade morfocultural e genética de fungos associados à podridão peduncular do mamão. Ciências Agrotécnicas, 27(5), 1053-1062. https://doi.org/10.1590/S1413-70542003000500012

Qi, Y. X., Zhang, X., Pu, J. J., Liu, X. M., Lu, Y., Zhang, H. Q., \& Xie, Y. X. (2011). Morphological and molecular analysis of genetic variability within isolates of Corynespora cassiicola from different hosts. European Journal of Plant Pathology, 130(1), 83-95. https://doi.org/10.1007/s10658-010-9734-6

Rasband, W. S. (2012). ImageJ: Image processing and analysis in Java. Astrophysics Source Code Library. Retreved from https://ui.adsabs.harvard.edu/abs/2012ascl.soft06013R/abstract

Seaman, W. L., Shoemaker, R. A., \& Peterson, E. A. (1965). Pathogenicity of Corynespora cassiicola on soybean. Canadian Journal Botany, 43, 1461-1469. https://doi.org/10.1139/b65-154

Shimomoto, Y., Adachi, R., Morita, Y., Yano, K., Kiba, A., Kikichi, Y., \& Takeuchi, S. (2008). Corynespora blight of sweet pepper (Capsicum annuum) caused by Corynespora cassiicola (Berk. \& Curt.) Wei. Journal of General Plant Pathology, 74(4), 335-337. https://doi.org/10.1007/s10327-008-0100-x

Sinclair, J. B., \& Backman, P. A. (1989). Compendium of soybean diseases. American Phytopathological Society.

Snow, J. P., \& Berggren, J. R. G. T. (1989). Target spot: Compendium of soybean diseases (3rd ed., pp. 27-28). St Paul, Minnesota: American Phytopathological Society.

Sousa, F. M. G., \& Bentes, J. L. S. (2014). Variability of Corynespora cassiicola (Berk. \& Curt.) Wei isolates from Amazonas, in culture media. Summa Phytopathologica, 40(1), 84-87. https://doi.org/10.1590/ S0100-54052014000100014

Spencer, J. A., \& Walters, H. J. (1969). Variations in certain isolates of Corynespora cassiicola. Phytopathology, $59(1), 58$.

Sumabat, L. G., Kemerait, J. R., \& Brewer, M. T. (2018). Phylogenetic diversity and host specialization of Corynespora cassiicola responsible for emerging target spot disease of cotton and other crops in the 
southeastern United States. Phytopathology, 108(7), 892-901. https://doi.org/10.1094/PHYTO-12-170407-R

Teramoto, A. (2008). Caracterização morfológica, fisiológica, isoenzimática e controle de isolados de Corynespora cassiicola (Berky \& Curt) Wei, agente causal da mancha alvo. Doutorado em Agronomia, Universidade Federal de Goiás, Brazil. Retrieved from https://repositorio.bc.ufg.br/tede/handle/tde/455

Wei, C. T. (1950). Notes on Corynespora. Mycological Papers, 34.

\section{Copyrights}

Copyright for this article is retained by the author(s), with first publication rights granted to the journal.

This is an open-access article distributed under the terms and conditions of the Creative Commons Attribution license (http://creativecommons.org/licenses/by/4.0/). 